\title{
STRATEGI KOMUNIKASI VOLUNTARY COUNSELING TEST (VCT) TERHADAP PENDERITA HIV/AIDS (ODHA) DI MALANG
}

\author{
Rizki Agung Novariyanto \\ IKIP Budi Utomo Malang, \\ Jl. Citandui 46, Kota Malang \\ e-mail: rizkiagungoke@yahoo.com
}

\begin{abstract}
HIV / AIDS is still one of the dreaded disease by a large part of society, because they still consider HIV / AIDS as a deadly disease, there is no cure and the disease is a curse. This is caused due to an incorrect myths about HIV / AIDS. Due to the myth, making people living with HIV / AIDS ( PLWHA ) are stigmatized and discrimination. Stigma and discrimination are two things that are often experienced by people living with HIV. Because of the stigma and discrimination that people living with HIV be afraid, afraid to open up for fear of being shut excluded so that people living with HIV and people living with HIV closure that makes HIV / AIDS is difficult to detect its spread. To overcome these problems , one of which is through Voluntary Counseling Test (VCT). VCT counseling is an activity that provides psychological support, information and knowledge of HIV / AIDS, prevent the transmission of HIV, promote responsible behavior change, treatment and ensure solving various problems associated with HIV / VCT AIDS.Ada in two stages, namely the stage of Pre- Test and Post-Tests. In the Pre-test counseling is done stage by providing information about HIV / AIDS, prevention, transmission and window period . Pre- test counseling provides knowledge about the benefits of HIV testing, testing for decision making, and planning for issues facing HIV . After HIV Testing and Counseling Pre PLWHA PLWHA undergo the HIV test will undergo stages of post counseling where PLHIV will be conditioned to accept the results of the HIV test, get information about what to do if the results of his HIV test is positive or negative, and most importantly so that people living with HIV do not become stress, depression and despair. VCT is run by counselors who are trained and experienced in this study bidangnya.Pada researchers conducted a study using qualitative methods to the three counselors that have been set using purposive sampling method and data captured through interviews and counseling in VCT observasi.Ketika Pre Test and post- test, the counselor needs a communications strategy that will be used to affect people living with HIV in order to receive the message delivered by the counselor and the main thing is to change the behavior of people living with HIV. Based on the results of research conducted by the researchers of the communication strategy VCT Pre Test and Post- Test in Dr. Saiful Anwar Hospital Malang against people living with HIV, it was found that the result is a persuasive communication strategies used by counselors when doing koneling to PLWHA HIV Testing Pre and Communication, Information andEducation (CIE) is a communication strategy that is used by counselors when counseling Post- test counseling is done by the counselor was tailored to what the existing problems in people living with HIV with the ultimate goal, namely a change in the behavior of people living with HIV.
\end{abstract}

Keywords : Communication Strategies Voluntary Counseling Test ( VCT ), people living with HIV / AIDS ( PLWHA)

Human Immunodeficiency Virus (HIV) adalah virus yang menyerang sistem kekebalan tubuh, yaitu sistem yang melindungi tubuh terhadap infeksi. Sistem kekebalan tubuh yang semakin lemah membuat orang mudah diserang oleh beberapa jenis penyakit (sindrom), penyakit itu disebut sebagai infeksi oportunistik. Infeksi oportunistik termasuk adanya penyakit jamur pada mulut, jenis kanker yang jarang, dan penyakit tertentu pada mata kulit dan sistem syaraf. Pada tahap inilah seseorang dinyatakan terinfeksi HIV yang masuk pada stadium infeksi berat atau disebut Acquired Immune Defficiency Syndrom (AIDS) (www.spiritia.or.id).
HIV/AIDS merupakan penyakit yang belum ditemukan obatnya hingga saat ini dan mendapatkan stigma negatif di mata masyarakat. Stigma negatif terhadap HIV / AIDS ini juga menimbulkan diskriminasi kepada penderitanya atau yang disebut dengan ODHA (Orang Dengan HIV/AIDS). Diskriminasi yang terjadi kepada ODHA, mengakibatkan ODHA menjadi pribadi yang tertutup, minder, serta mengucilkan diri dari pergaulan masyarakat di sekitarnya. Hal inilah yang menjadi salah satu penyebab sulitnya mendeteksi penyebaran HIV/AIDS di masyarakat (Liliweri : 2007). 
Oleh karena itu banyak Rumah Sakit dan Puskesmas yang membuka Klinik Voluntary Conseling and Testing (VCT) yang melayani para penderita HIV/AIDS secara sukarela. VCT adalah kegiatan konseling yang menyediakan dukungan psikologis, informasi dan pengetahuan tentang HIV/AIDS, mencegah penularan HIV, mempromosikan perubahan perilaku yang bertanggung jawab, pengobatan ARV dan memastikan pemecahan berbagai masalah terkait HIV / AIDS. Konseling pada VCT yang dilakukan secara sukarela merupakan salah satu strategi kesehatan masyarakat sebagai pintu masuk ke seluruh layanan kesehatan HIV dan AIDS yang berkelanjutan. Program VCT dapat dilakukan berdasarkan kebutuhan pasien dengan memberikan layanan dini dan memadai baik kepada mereka dengan HIV positif dan negatif Layanan ini termasuk pencegahan primer melalui Komunikasi, Informasi dan Edukasi (KIE) seperti pemahaman HIV, pencegahan penularan dari ibu ke anak Prevention of Mother To Child Transmission (PMCT) dan akses terapi infeksi oportunistik seperti tuberkulosis (TBC) dan infeksi menular seksual (kpa.provsu.og).

VCT dikerjakan secara professional dan konsisten untuk memperoleh intervensi efektif, dimana memungkinkan pasien dengan bantuan konselor terlatih menggali dan memahami diri akan resiko HIV/AIDS, mempelajari status dirinya, mengerti tanggung jawab untuk menurunkan perilaku berisiko dan mencegah penularan infeksi kepada orang lain guna mempertahankan dan meningkatkan perilaku sehat. VCT merupakan kegiatan konseling yang bersifat sukarela dan rahasia yang dilakukan sebelum dan sesudah tes darah untuk HIV di laboratorium. Meskipun VCT adalah sukarela, namun utamanya diperuntukkan bagi orangorang yang sudah terinfeksi HIV atau AIDS, dan keluarganya, atau semua orang yang mencari pertolongan karena merasa telah melakukan tindakan berisiko di masa lalu dan merencanakan perubahan di masa depannya, serta mereka yang tidak mencari pertolongan namun berisiko tinggi (kpa.provsu.og).

VCT terdapat dua kegiatan utama yaitu konselling dan Tes HIV. Konseling dilakukan oleh seorang konselor khusus yang telah dilatih untuk memberikan konseling VCT. Tetapi tidak semua konselor bisa dan boleh memberikan konseling, karena seorang konselor VCT adalah orang yang telah mendapat pelatihan khusus dengan standar pelatihan nasional. Konseling dalam rangka VCT utamanya dilakukan sebelum dan sesudah Tes HIV. Konseling setelah Tes HIV dapat dibedakan menjadi dua, yakni konseling untuk hasil positif dan konseling untuk hasil tes negatif. Pada konseling untuk hasil tes negatif, disarankan kepada pasien yang mempunyai perilaku resiko tinggi untuk kembali melakukan VCT sesudah 3 bulan, karena pasien pada saat tersebut mungkin sedang dalam periode jendela. Disamping itu pasien juga disarankan untuk mengurangi perilaku beresiko. Pada konseling pra Tes HIV, seseorang disiapkan untuk melakukan pemeriksaan darah atau Tes HIV dengan materi-materi yang diberikan seperti proses konseling dan Tes HIV sukarela, manfaat Tes HIV, pengertian tentang HIV/AIDS, meluruskan pemahaman yang salah tentang HIV/ AIDS dan mitosnya, membantu pasien mengetahui faktor resiko penularan HIV/AIDS, menyiapkan pasien untuk pemeriksaan darah, mendiskusikan kemungkinan hasil Tes HIV positif dan negatif, persetujuan untuk tes HIV sukarela, mengembangkan rencana perubahan perilaku yang sehat dan aman. Sementara itu, pada konseling pasca Tes HIV, pasien dibantu untuk memahami dan menyesuaikan diri dengan hasil tes. Materi konseling yang diberikan adalah mengenai penjelasan tentang hasil Tes HIV. Jika hasil tes positif, petugas konseling akan menyampaikan hasil tes dengan cara yang dapat diterima pasien secara halus dan manusiawi (kpa.provsu.og).

Melalui VCT, diharapkan pasien mau membuka diri dan melakukan Tes HIV, sehingga diketahui apakah pasien tersebut positif tertular HIV/AIDS atau masih negatif. Untuk itulah diperlukan strategi komunikasi yang tepat dan terencana oleh konselor ketika melakukan konseling kepada pasien. Karena dengan strategi yang tepat dan terencana, maka konselor bisa mempengaruhi dan mengubah persepsi pasien tentang HIV/AIDS. Penelitian ini dilakukan di Rumah Sakit Umum Dr. Saiful anwar Malang (RSSA) terhadap empat konselor, yaitu konselor psikolog, konselor perawat, konselor Manajer kasus (MK) dan konselor kelompok dukungan sebaya (KDS) dengan metode wawancara tersrtuktur dan observasi tidak terstruktur untuk 
untuk menganalisis Strategi Komunikasi VCT HIV/AIDS terhadap ODHA pra tes, pasca tes dan strategi komunikasi VCT yang disesuaikan dengan kebutuhan ODHA. Berdasarkan pokok permasalahan yang dibahas di latar belakang, maka rumusan masalah dari penelitian ini adalah (1) Bagaimana implementasi Strategi Komunikasi Voluntary Counseling Test (VCT) pada Orang dengan HIV/AIDS (ODHA) Pra Tes HIV di Rumah Sakit Umum Dr Saiful Anwar (RSSA) Kota Malang? (2) Bagaimana implementasi Strategi Komunikasi Voluntary Counseling Test (VCT) pada Orang dengan HIV/AIDS (ODHA) Pasca Tes HIV di Rumah Sakit umum Dr Saiful Anwar (RSSA) Kota Malang? Dan (3) Bagaimana implementasi Strategi Komunikasi Voluntary Counseling Test (VCT) yang disesuaikan dengan kebutuhan Orang dengan HIV/ AIDS (ODHA) di Rumah Sakit Umum Dr Saiful Anwar (RSSA) Kota Malang?

Dari penelitian yang dilakukan terhadap empat konselor di Rumah Sakit Umum Dr Saiful Anwar Malang (RSSA), yang terdiri dari konselor psikolog, konselor perawat, konselor manajer kasus (MK) dan Konselor kelompok dukungan sebaya (KDS), diketahui bahwa strategi komunikasi yang digunakan oleh konselor ketika melakukan VCT adalah dengan memberikan pemahaman, informasi yang benar tentang HIV/AIDS, pendampingan dan motivasi melalui pendekatan secara personal, menunjukkan rasa empati dan memberikan penjelasan dengan disertai contoh dan buktibukti yang nyata.berikut ini diuraikan strategi komunikasi yang digunakan oleh keempat konselor ketika melakukan konseling kepada pasien, (Liliweri, 2007).

\section{METODE}

Penelitian ini menggunakan metode penelitian kualitatif dengan pendekatan studi kasus. Penelitian ini akan menjawab pertanyaan apa dan mengapa (Burhan, 2001). Tahapan pertama pada penelitian ini adalah observasi awal. Pada kegiatan observasi awal peneliti mencari bagaimana bentuk komunikasi kepada pasien dari masing-masing konselor. Pendekatan personal dari masing-masing konselor memang dirasakan sulit untuk menyesuaikan diri. Demi memperoleh data yang tidak menimbulkan bias peneltiian maka diperlukan indepth interview atau wawancara mendalam kepada masing-masing konselor dan para penderita HIV AIDS. Dengan dilengkapi metode snow ball sampling akhirnya peneliti mendapatkan informasi yang lengkap tentang proses komunikasi pada konselor terhadap ODHA.

\section{Strategi Komunikasi Voluntary Counseling Test (VCT) HIV/AIDS Konselor Psikolog}

Wedia adalah konselor psikolog VCT HIV/AIDS di Rumah Sakit Umum Dr. Saiful Anwar Malang. Ketika melakukan konseling kepada pasien, Mas Wedia menggunakan pendekatan personal dan memposisikan dirinya sebagai seorang teman. Dengan memposisikan diri sebagai seorang teman, maka konselor akan menjadi lebih dekat dengan pasien dan mampu merasakan apa yang dirasakan oleh pasien atau yang disebut dengan empati. Melalui pendekatan secara pribadi, maka konselor akan dengan mudah memberikan motivasi dan pemahaman-pemahaman yang benar mengenai HIV / AIDS baik itu pra tes, pasca tes dan memberikan konseling sesuai dengan kebutuhan pasien. Strategi-strategi yang digunakan oleh konselor ketika memberikan pemahaman kepada pasien adalah dengan menggunakan pengalamannya sebagai seorang konselor, dengan memberikan penjelasan menggunakan data-data dan fakta yang bisa dipertanggung jawabkan. Kemudian konselor menampilkan keahlian-keahliannya, sebagai seorang komunikator untuk menimbulkan kepercayaan kepada diri pasien, seperti menampilkan kepakarannya, karakternya kewenangannya untuk mempengaruhi pasien, terutama mempersiapkan mental pasca tes dan merubah persepsi mereka tentang HIV/AIDS dan. Konselor juga menggunakan metode koersif dalam strategi komunikasi untuk mempengaruhi pasien yang keras kepala dan tidak mau menuruti apa yang disarankan oleh konselor.

Konseling yang dilakukan oleh konselor kepada pasien tujuannya adalah agar pasien mau membuka diri atau yang disebut dengan Self Disclosure (Joseph: 1996). Self Disclosure merupakan pemberian informasi yang dilakukan oleh komunikator (pasien kepada seorang konselor (komunikan), dimana pemberian informasi itu dilakukan secara aktif tanpa ada yang disembunyikan lagi. Denganß (seharusnya 
dihapus) Pada waktu menunjukkan Trustnya kepada konselor yang diwujudkan melalui strategi-strategi komunikasi yang digunakan ketika memberikan konseling kepada pasien, maka konselor berharap pasien akan membuka diri yang bisa berfungsi sebagai ekspresi diri, penjernihan diri dan mempunyai manfaat dan keuntungan seperti sebagai sarana pelepasan diri, menciptakan mental yang sehat dan melindungi diri dari stress. Tahap-tahapan yang dilakukan ketika konselor melakukan konseling dari awal sampai akhir, terdiri dari tiga langkah dalam teori penetrasi sosial, yaitu tahap luar dimana komunikasi yang tterjadi anatara konselor dan pasien masih bersifat basa - basi atau saling menjaga jarak, kemudian tahap penjajakan, dimana komunikasi sudah berlangsung secara lebih lancar, antara konselor dan pasien sudah saling membuka diri dan mengenal satu sama lain. Yang terakhir adalah Tahap akhir, dimana komunikasi antara konselor dengan pasien sudah terjalin sangat dekat dan tidak ada lagi yang disembunyikan ketika melakukan komunikasi.

\section{Strategi Komunikasi Voluntary Counseling Test (VCT) Hiv/Aids Konselor Perawat}

Bu Endang adalah konselor perawat VCT HIV / AIDS di Rumah Sakit Umum Dr Saiful Anwar Malang (RSSA). Ketika melakukan konseling, Bu Endang memposisikan diri sebagai seorang teman dan mencoba merasakan apa yang dirasakan oleh pasien atau apa yang disebut dengan empati. Melalui pendekatan secara personal, maka konselor akan dengan mudah memberikan pemahaman kepada pasien, terutama meluruskan mitos yang salah dan mengubah persepsi pasien tentang HIV/ AIDS. Konselor memberikan penjelasan kepada pasien disertai contoh - contoh dan fakta-fakta yang bisa dipertanggungjawabkan baik itu pra tes, pasca tes dan ketika memberikan konseling menggunakan metode KIE, terutama ketika mempersiapkan mental pasien untuk menghadapi hidup dengan HIV/ AIDS. Strategistrategi komunikasi konselor juga diwujudkan melalui keahliannya dalam menapilkan kepakaran, karakter, dan kewenangannya untuk menarik perhatian pasien. Jika ada pasien yang masih tidak mau menuruti saran dari konselor dan putus harapan, maka konselor akan terus menerus memberikan pemahaman dan motivasi secara berulang.

Konseling yang dilakukan oleh konselor kepada pasien tujuannya adalah agar pasien mau membuka diri atau yang disebut dengan Self Disclosure. Self Disclosure merupakan pemberian informasi yang dilakukan oleh komunikator (pasien kepada seorang konselor (komunikan), dimana pemberian informasi itu dilakukan secara aktif tanpa ada yang disembunyikan lagi.Dengan menunjukkan Trustnya kepada konselor yang diwujudkan melalui strategistrategi komunikasi yang digunakan ketika memberikan konseling kepada pasien, maka konselor berharap pasien akan membuka diri yang bisa berfungsi sebagai ekspresi diri, penjernihan diri dan mempunyai manfaat dan keuntungan seperti sebagai sarana pelepasan diri, menciptakan mental yang sehat dan melindungi diri dari stress. Tahap-tahapan yang dilakukan ketika konselor melakukan konseling dari awal sampai akhir, terdiri dari tiga langkah dalam teori penetrasi sosial, yaitu tahap luar dimana komunikasi yang tterjadi anatara konselor dan pasien masih bersifat basa - basi atau saling menjaga jarak, kemudian tahap penjajakan, dimana komunikasi sudah berlangsung secara lebih lancar, antara konselor dan pasien sudah saling membuka diri dan mengenal satu sama lain. Yangßharusnya dihapus Tahap terakhir adalah Tahap akhir, dimana komunikasi antara konselor dengan pasien sudah terjalin sangat dekat dan tidak ada lagi yang disembunyikan ketika melakukan komunikasi.

\section{Strategi Komunikasi Voluntary Counseling Test (VCT) HIV/AIDS Konselor Manajer Kasus (MK)}

Konseling pada Manajer Kasus (MK) dilakukan oleh Mas Benny Handoyo sejak tahun 2011. Mas Benny Handoyo adalah seorang konselor dan aktif sebagai aktivis Ikatan Gay Malang (IGAMA). Ketika melakukan konseling, konselor melakukan pendekatan secara personal kepada pasien dan bersifat tidak formal, dimana konseling bisa dilakukan dimana saja sesuai keinginan pasien serta konselor juga siap melakukan pendampingan terutama pendampingan ketika melakukan pengobatan. Melalui pendekatan secara personal dan 
menganggap pasien sebagi teman maka konselor akan dengan mudah memberikan pemahamanpemahaman kepada pasien terutama mengenai layanan - layanan yang terdapat pada VCT dan disesuaikan dengan kebutuhan pasien.Strategistrategi komuniaksi yang digunakan oleh konselor seperti memberikan penjelasan menggunakan pengalamannya disertai dengan data dan fakta yang dapat dipertanggung jawabkan dialkukan oleh konselor untuk memberikan pemahaman kepada pasien yang masih belum benar-benar mengerti tentang HIV / AIDS. Kemudian konselor juga akan menggunakan kepakarannya, kewenangannya, kemauan baiknya dan karakternya agar pasien mau menceritakan permasalahan apa yang dihadapinya pasca tes HIV / AIDS dan bersamasama mencari pemecahan masalah atau solusi.Setiap bulan, konselor rutin melakukan evaluasi kepada pasien terutama untuk masalah pengobatan. Kepada pasien yang sudah tidak rutin lagi melakukan pengobatan, maka konselor akan memberikan lagi pemahaman dan motivasi.

Konseling yang dilakukan oleh konselor kepada pasien tujuannya adalah agar pasien mau membuka diri atau yang disebut dengan Self Disclosure. Self Disclosure merupakan pemberian informasi yang dilakukan oleh komunikator (pasien kepada seorang konselor (komunikan), dimana pemberian informasi itu dilakukan secara aktif tanpa ada yang disembunyikan lagi. Dengan menunjukkan Trustnya kepada konselor yang diwujudkan melalui strategi-strategi komunikasi yang digunakan ketika memberikan konseling kepada pasien, maka konselor berharap pasien akan membuka diri yang bisa berfungsi sebagai ekspresi diri, penjernihan diri dan mempunyai manfaat dan keuntungan seperti sebagai sarana pelepasan diri, menciptakan mental yang sehat dan melindungi diri dari stress. Tahap-tahapan yang dilakukan ketika konselor melakukan konseling dari awal sampai akhir, terdiri dari tiga langkah dalam teori penetrasi sosial, yaitu tahap luar dimana komunikasi yang tterjadi anatara konselor dan pasien masih bersifat basa - basi atau saling menjaga jarak, kemudian tahap penjajakan, dimana komunikasi sudah berlangsung secara lebih lancar, antara konselor dan pasien sudah saling membuka diri dan mengenal satu sama lain. Yang terakhir adalah Tahap akhir, dimana komunikasi antara konselor dengan pasien sudah terjalin sangat dekat dan tidak ada lagi yang disembunyikan ketika melakukan komunikasi.

\section{Strategi Komunikasi Voluntary Counseling Test (VCT) HIV/AIDS Konselor Dukungan Sebaya (KDS)}

Konselor KDS (kelompok Dukungan Sebaya) adalah Mas Indra, beliau juga merupakan seorang Orang Dengan HIV AIDS (harusnya hilang) (ODHA).Sehingga ketika melakukan konseling Mas Indra bisa merasakan apa yang dirasakan oleh pasien dan bisa menunjukkan dengan realita dan fakta bagaimana kehidupan ODHA sesungguhnya. Dengan latar belakang sebagai seorang ODHA, maka Mas Indra akan dengan mudah menarik perhatian pasien untuk mengikuti apa yang disarankan. Disamping itu konselor juga akan menunjukkan kepakaran, karakternya dan kemauan baiknya kepada pasien ketika memberikan motivasi dan pemahaman pemahaman serta agar pasien mau membuka diri dan menceritakan permasalahanpermasalahan apa yang dihadapinya (Sutaryo, 2005). Jika ada pasien yang keras kepala dan masih tidak mau mengikuti apa yang disarankan oleh konselor, maka konselor akan menggunakan metode koersif, dengan mengemukakan resiko - resiko apa yang akan dihadapi oleh paisn, terutama jika pasien tidak mau melakukan pengobatan secara rutin dan mengurangi perilaku yang beresiko.

Konseling yang dilakukan oleh konselor kepada pasien tujuannya adalah agar pasien mau membuka diri atau yang disebut dengan Self Disclosure. Self Disclosure merupakan pemberian informasi yang dilakukan oleh komunikator (pasien kepada seorang konselor (komunikan), dimana pemberian informasi itu dilakukan secara aktif tanpa ada yang disembunyikan lagi.Dengan menunjukkan Trustnya kepada konselor yang diwujudkan melalui strategistrategi komunikasi yang digunakan ketika memberikan konseling kepada pasien, maka konselor berharap pasien akan membuka diri yang bisa berfungsi sebagai ekspresi diri, penjernihan diri dan mempunyai manfaat dan keuntungan seperti sebagai sarana pelepasan 
diri, menciptakan mental yang sehat dan melindungi diri dari stress. Tahap-tahapan yang dilakukan ketika konselor melakukan konseling dari awal sampai akhir, terdiri dari tiga langkah dalam teori penetrasi sosial, yaitu tahap luar dimana komunikasi yang terjadi anatara konselor dan pasien masih bersifat basa - basi atau saling menjaga jarak, kemudian tahap penjajakan, dimana komunikasi sudah berlangsung secara lebih lancar, antara konselor dan pasien sudah saling membuka diri dan mengenal satu sama lain. Yang terakhirß Diganti Selanjutnya adalah Tahap akhir, dimana komunikasi antara konselor dengan pasien sudah terjalin sangat dekat dan tidak ada lagi yang disembunyikan ketika melakukan komunikasi.

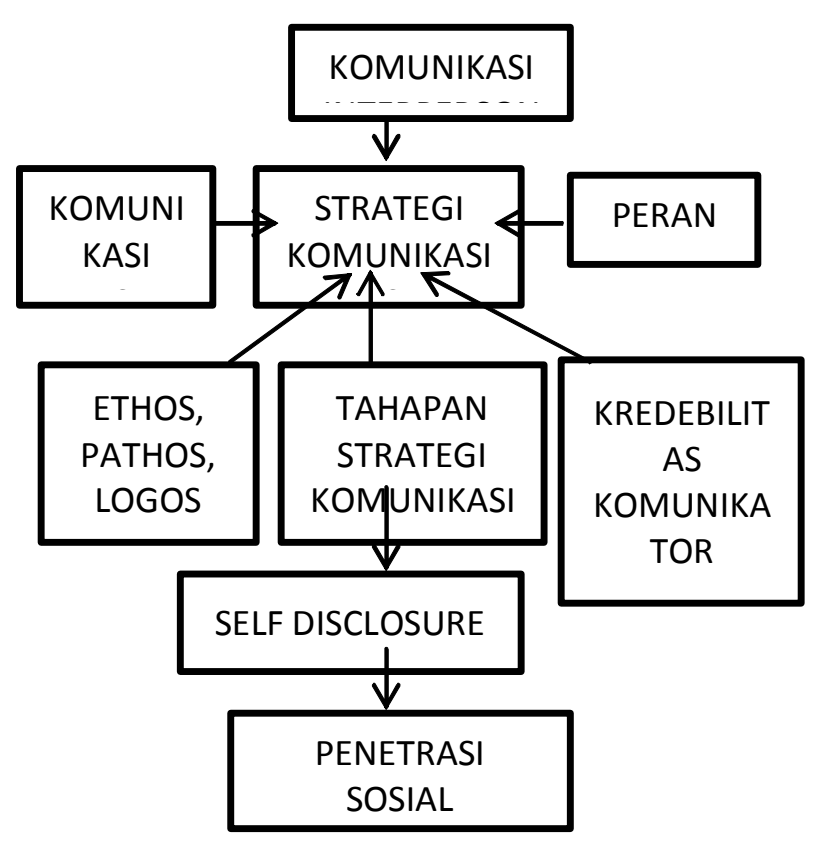

\section{KESIMPULAN}

Strategi komunikasi adalah bagian penting dari proses konseling yang dilakukan oleh Konselor kepada pasien HIV/AIDS baik positif maupun negative Melalui strategi komunikasi konselor berusaha mempengaruhi pasien agar mau menuruti apa yang disarankan oleh konselor, seperti melakukan Tes HIV, rutin melakukan pengobatan, meninggalkan kegiatan yang beresiko mengakibatkan penularan dan penyebaran HIV/AIDS serta yang utama adalah memberikan banyak informasi dan meluruskan mitos yang salah tentang HIV/AIDS kepada pasien.

Ada empat konselor dalam Voluntary Counseling Test (VCT), yaitu dua konselor dengan latar belakang sebagai seorang psikolog dan perawat dan satu konselor yang merupakan seorang aktivis dari Ikatan Gay Malang (IGAMA). Mereka bertiga memberikan konseling kepada pasien dengan HIV positif / negatif atau yang biasa disebut ODHA di Rumah Sakit Saiful Anwar Malang (RSSA). Serta seorang konselor dari Kelompok Dukungan Sebaya (KDS) yang memberikan konseling secara tidak formal kepada pasien. Keempatnya memiliki tujuan yang sama dalam melakukan konseling kepada pasien, hanya ada sedikit perbedaan. Konselor VCT dari latar belakang keilmuan psikolog melakukan pendekatan secara personal dan menggunakan pengalamannya sebagai seorang konselor ketika memberikan penjelasan kepada pasien. Keahlian konselor sebagai seorang psikolog juga digunakan ketika melakukan konseling, kemudian konselor psikolog terkadang menggunakan metode koersif kepada pasien yang bandel. Dalam arti sulit untuk mengubah perilaku berisikonya dan melakukan pengobatan secara rutin walaupun telah diberi pemahaman secara berulang - ulang.

Konselor dengan latar belakang perawat melakukan konseling juga dengan menggunakan pendekatan personal dan menggunakan pengalamannya sebagai seorang konselor untuk mempengaruhi pasien.Konselor perawat lebih sabar dalam memberikan konseling dengan menganggap pasien sebagai teman bahkan sebagai saudara. Sedangkan konselor Manajer Kasus (MK) melakukan konseling secara tidak formal dan melakukan pendekatan secara personal kepada pasien, kedekatan secara personal itu ditunjukkan dengan adanya konseling yang bisa berlangsung di rumah pasien atau melalui telepon san SMS. Konselor yang terakhir adalah konselor dari Kelompok Dukungan Sebaya (KDS), yang juga seorang ODHA dan memeberikan konseling drngan menggunakn pengalaman yang dia miliki sebagai seorang ODHA dan menunjukkan realitas bagaimana kehidupan seorang ODHA sebenarnya. Dengan menunjukkan realitas yang ada, konselor KDS berharap pasien akan terbuka pikirannya, mendapatkan informasi yang benar tentang HIV/AIDS, dan tetap bersemangat menjalani hidup sebagai seorang ODHA.

Konseling dilakukan pra tes, pasca tes dan konseling yang dilakukan sesuai dengan 
kebutuhan pasien. Dengan konseling yang dilakukan oleh konselor kepada pasien, diharapakan selain pasien mau mengubah pikiran dan persepsinya tentang HIV/AIDS, pasien akan membuka diri atau yang disebut dengan Self Disclosure. Melalui Self Disclosure,pasien akan menceritakan masalahmasalah apa saja yang dihadapi terkait dengan HIV/AIDS, sehingga konselor bisa membantu mencarikan solusi atas permasalahan yang sedang dihadapi oleh pasien.

\section{DAFTAR RUJUKAN}

\section{Buku:}

Bungin, B. 2001. Metode Penelitian Sosial, Format Kuantitatif dan

Kualitatif Surabaya : Airlangga U. P

Bungin, B. 2009. Sosiologi Komunikasi : Teori,

Diskursus Teknologi Komunikasi Di

Masyarakat. Jakarta: Kencana Prenada Group

De Vito, J. A.1996.Komunikasi Antar Manusia.Jakarta : Professional

Books
Liliweri, A.2007.Dasar-Dasar Komunikasi Kesehatan. Yogyakarta:Pustaka Pelajar Sutaryo. $2005 . \quad$ Sosiologi

Komunikasi.Yogyakarta: Arti Bumi Intaran

\section{Internet :}

Definisi,Sejarah, Gejala, Cara Penularan dan Penyebaran HIV AIDS hanifatunissa.wordpress.com. Diakses 1011-2012, pukul $21.00 \mathrm{wib}$

Orang yang Beresiko Tertular HIV AIDS.MakhlukSurga.BlogSpot.com Diakses 10-11-2012, pukul 21.15

Anti Stigma dan Diskriminasi Terhadap ODHA.dofan.wordpress.com Diakses 1011-2012, pukul 20.15

Cara Mencegah HIV Aids Secara Efektif.Carakata.blogspot.com Diakses 1311-2012, pukul 19.11

Definisi VCT. Kpa.provsu.og. Diakses 1311-2012, pukul 19.25 
52|| Rizki Agung Novariyanto, Strategi Komunikasi Voluntary ..... 